\title{
DETERMINANTS OF MARKETING PERFORMANCE: INNOVATION, MARKET CAPABILITIES AND MARKETING PERFORMANCE
}

\section{Naili Farida}

Faculty of Social and Political Science, Diponegoro University, Semarang, Indonesia

\section{Info Article}

History Article:

Received Desember 2015

Approved January 2016

Published March 2016

\section{Keywords:}

Innovation;

Market Capability;

Marketing Performance.

\begin{abstract}
This research aim to analyze causality influence between innovations, market capability, social modal, entrepreneurs oriented into marketing performance. Organizational innovations is a basic focus on Total Quality Management. Innovation has a role to technological development and competitive economy environment. The sample technique used is Purpusive sampling amount 58 respondent owner of Batik Small Medium Enterprise known as UKM. Small businesses have small medium or medium can grow and develop so that it is able to increase its product and sustainability efforts on the creative industry. The technique analysis used is Parsial Least Square (PLS), this result shows entrepreneur orientation doesn't influence into market capability and social modal, innovation has positive influence and significance into market capability and marketing performance. This results shows innovation has important role in advantaging market capability while influencing to increase marketing performance of Small Medium Enterprise known as UKM.
\end{abstract}

\section{FAKTOR PENENTU KINERJA PEMASARAN: INOVASI, KEMAMPUAN PASAR DAN KINERJA PEMASARAN}

\begin{abstract}
Abstrak
Penelitian ini bertujuan untuk menganalisis pengaruh kausalitas antara inovasi, kemampuan pasar, modal sosial, pengusaha berorientasi ke kinerja pemasaran. Inovasi organisasi adalah dasar TQM. Inovasi mempunyai peran pentinga dalam pengembangan teknologi dan lingkungan yang penuh persaingan. Teknik sampel yang digunakan adalah Purposive Sampling jumlah 58 pemilik responden dari Batik Kecil Menengah dikenal sebagai UKM. UKM dapat tumbuh dan berkembang melalui industri kreatif. Teknik analisis yang digunakan adalah Parsial Least Square (PLS), hasil ini menunjukkan orientasi entrepreneur tidak mempengaruhi ke kemampuan pasar dan modal sosial, inovasi berpengaruh positif dan signifikan dalam kemampuan pasar dan kinerja pemasaran. Hal ini menyebabkan menunjukkan inovasi memiliki peran penting dalam advantaging kemampuan pasar sementara yang mempengaruhi untuk meningkatkan kinerja pemasaran Kecil Menengah dikenal sebagai UKM.
\end{abstract}

JEL Classification: M3, M31 


\section{Naili Farida / Determinants of Marketing Performance...}

\section{INTRODUCTION}

At the time of the free market Economy or ASEAN Economic Society Era, open market potential with a population nearly 625 million from 10 countries include Indonesia, Malaysia, Singapore, Thailand, Brunei Darussalam, Philippines, Laos, Cambodia and Myanmar. Competitions are between companies and countries have been underway, but the product become increasingly tight competition need innovation product in order to compete with other countries needs to be improved. One of the potential wealth products from Indonesia is batik which has recognized by UNESCO as a superior product that has been growing rapidly. Therefore, small businesses have small medium or medium can grow and develop so that it is able to increase its product and sustainability efforts on the creative industry.

Some research suggests Tang et al. (2007), variable entrepreneurial orientate on or entrepreneurship orientations with the dimensions indicator are pro active, innovation and risk taking on performance marketing with hierarchy Moderated regression analysis techniques shows the research results findings in significant positive effect. Other studies shows the different results Merlo and Auh (2009)cexplaining variable of entrepreneurship orientations with the indicator dimensions of innovativeness, risk-taking and pro activeness and regression analysis techniques of this study states that significant entrepreneurial orientation has no effect on performance marketing, this indicates the research existence gap that is the entrepreneurial orientation research on performance marketing. The outline of this research focuses on how to develop a model gap of the entrepreneurial orientation to improve marketing performance?

\section{Hypothesis Development}

Innovation has five indicators, namely production innovation such as design changes, of products, components and architecture innovation services namely serving consumers and new forms of services, innovation processes relates to existing adaptation product lines and technology implementation or new process. Innovation-relates market penetration of new market segments and logistics innovation is a new logistic model to achieve raw material and or- ganizational innovations, namely a new managerial system in the Organization (Neely et al, 2001). In line with technological developments and competitive economy environment the role of innovation have an important part to the company success in competition.

Next Mavondo et al. (2005) states innovation has three dimensions of innovation, namely administration, innovation and product innovation, process innovation only, whereas bases on MariamIsmail (2005) innovation there are two innovations explain as follow innovation relates to technology transfer and organizational innovations with basic focus on Total Quality Management (TQM). Innovation in this study uses 1) Product innovation, new product development, namely 2 ) innovation process as follows develop products by different raw materials, 3) Innovation market segmentation are different markets to meet consumers necessities and desiring. 4) Innovation services in consumers service and 5) production innovation.

\section{Social Modal}

The study of the social capital is the values and norms of a particular shares among members of a group that allows a cooperation among them (Coleman, 1988; Villena et al., 2011; Weber \&Weber, 2011; Wincent et al., 2013; Wincent et al., 2014) states that social capital is a network together with the values and norms of the same understanding that facilitating cooperation within and among groups. According to Ferdinand (2005) and Cooke (2007), Social capital includes: networks of relationships, social Networks, social Cohesion, mutual trust and social norms. Social capital in the research includes 1) networking relationships, 2) social Networking), 3) social Cohesion, 4) trust and 5) social norms.

\section{Enterpreneurial Orientation}

According to Griffith et al, 2006 explaining that entrepreneurial orientation can improve the company associated information collection with customers, competitors, suppliers and markets so that it can push the development company ability. Haroon and Kocak (2011) indicating that entrepreneurial orientation is often describes as a mindset in helping company to grow and do even better. Weerawerdana 
(2003) defines the orientation of entrepreneurship is a way of looking at managing assessing company with experience of trying, proactively, dare to take the risk, flexible and anticipatory. The next in this study uses 5 dimensions as follows: 1) having experience of trying, is pro active, dare to take risks, flexible and anticipatory.

\section{Market Capabilities}

The theory of Resources Based View (RBV) first expressed by Wernefelt, 1984 that the resources and the company ability determine the company prominence compete and enjoy a competitive advantage compare to competitors and the company gaineda significant advantage compare with competitors. RBV developed focus on resources from the company internal side. According to Grant (1991), explains the importance resources and company capabilities that is the main source of competitive advantage and will enhance the competitor efforts to impersonation.

According to the Day (1994) the Resource bases views evolveinto a highly influential theory in the management field are: strategic marketing management. Further Teece et al. (1997) states that Resource based value (RBV) is the approach uses company to achieve a sustainable competitive advantage bases on resource Barney (1991), Narver and Slater (1990) defines 4 indicators of the market ability as follows: understanding business environment, change design creations, the function of the uniqueness product, and the competition capability.

\section{Marketing Performance}

Marketing performance as a business measurement of the company success rate includes sales turnover, number of customers, sales and growth profitability Voss and Voss (2000). While Saeko et al.(2012) states marketing performance is key to the business success as a result of market strategy for customers, market, and these financial organizations, the market performance such as sales growth, market share and market development in the study of marketing performance. The other study showed that good marketing performance expresses in three primary focus as follows the value of sales, sales growth and the share of market that finally is able to increase the company profits (Ferdinand, 2014).

\section{Social Capital And Market Capabilities}

Social capital is the values and norms of a particular shared among members of a group that allows a cooperation between them (Coleman, 1988; Villena et al., 2011; Weber \& Weber, 2011; Wincent et al., 2013; Wincent et al., 2014). Subsequently Ferdinand (2005) stating that the capital is an organizational network that is built on the basis norms together with the values system and the understanding sharesthat can strengthen cooperation and long-term social cohesion. Further by having the social capital which include: network of relationships, social networks, social Cohesion, mutual trust and social norms. Social capital in this research includes 1) networking relationships, 2) social Networking), 3) social cohesion, 4) trust and 5) social norms, social capital, owned by willing be able to improve the market capabilities in line with the increase resources. The other study states that the ability of the market are understanding business environment, change design creations, the function of the uniqueness product, and the competitioncapability (Narver \& Slater, 1990; Barney, 1991). So by having social capital will be able to improve the market capabilities getting better social capital, it will be the higher market capabilities. So it is constructed as the hypothesis.

\section{Enterpereneurship and Market Capabilities}

Entrepreneurial orientation capability is further Lumpkin and Dess (1996) States the entrepreneurial orientation has five aspects, namely autonomy, innovativeness, risk taking, pro activeness and competitive aggressiveness will spur companies to see its future actively so as to exploit market opportunities before other companies can create new opportunities. A good entrepreneurial orientation will be able to improve the market capabilities that every company has a unique resource capabilities and the company growth that are under on the efficiency of resource use and the spread of existing capabilities (Wernefelt, 1984; Paulina \& Wardoyo, 2012). The higher entrepreneurial orientation is the higher market capability, so it is constructed as hypothesis.

\section{Innovation and Market Capabilities}

According to Drucker (1986) innovation is an idea, practice or objects are perceived as something 


\section{Naili Farida / Determinants of Marketing Performance...}

new by individuals or units to be adopted in other. Further Hine and Ryan (1999) mentions there are six types of innovation, namely administrative, technical innovation, product innovation, process innovation, radical and incremental. Innovation on products have an important role to enhance the market capabilities where the competition is increasingly competitive accordance with continuous product innovation willing be able to improve the market capabilities. The higher innovation, it will be increasingly strong market capability, next to built the hypothesis.

\section{Market Capabilities and Marketing Perfor- mance}

The market has an important role capability as the resources and company capabilities in determining the competitive advantage competitors so that companies have a significant advantage than competitors (Grant,1991; Yulianto, 2010). The high market capacity will be able to affect the performance of a marketing company. According to Saeko et al. (2012) states performance marketing is key to the business success as a result of market strategy for customers, the market, and these benefits financially for the organization, its marketing performance such as sale, growing market share. The higher market capability, then the higher marketingperformance, then built the hypothesis.

\section{METHOD}

This research uses a quantitative approach that is explanatory research through survey methods, namely by means disseminating the questionnaire respondents that showed at Table 1. The population in this study is small and medium business owners of batik in Lasem city as many as 58 people. The technique used is the Purposive side of the sampling criteria: a) a small business owner Respondents) medium batik, b) long effort for a minimum 2 years, c) willing to fill a questionnaire and interviewed and d) Domicile in the small and medium business owners in Lasem city. Measurement scale is divided into five variations as follows: 1) strongly agree, 2) agree, 3 Neutral, 4) disagreed and 5) strongly disagree.

\section{Convergent Validity}

Convergent validity of measurement models with reflexive indicators assess bases on the correlation between the item score/component score that is being estimated with SmartPLS software. According to Ghozali (2013) to study the early stages of developing measurement scale of the value of 0.5 to 0.6 loading is considered quite adequate.

\section{Discriminant Validity}

Discriminant validity on indicators reflexive can be seen on the cross loading. Cross loading is useful to assess whether invalid constructs have a discriminant validity is adequate by way of relationships comparing between an indicator variable with the indicator correlation with other variables. If the relationship indicators invalid constructs have higher values compared to indicator's relationship towards other variables, then it is said invalid constructs have high discriminant validity.

\section{Average Variance Extracted}

The other Test is assessing the validation by looking at the value of the Average Variance Extracted (AVE), required a good model is the model that has the AVE each invalid constructs the value greater than 0.50 (Ghozali,2013).

Table1. The Value of Square Root AVE (Average Varianve Extracted)

\begin{tabular}{lcc}
\hline & AVE & $\sqrt{\boldsymbol{A V} \boldsymbol{E}}$ \\
\hline I & 0,5288 & 0,7271 \\
KP & 0,6309 & 0,7942 \\
MS & 0,5331 & 0,7301 \\
OK & 0,4025 & 0,6344 \\
P & 0,6215 & 0,7883 \\
\hline
\end{tabular}

On the table are obtained throughout the root value $0.5>\mathrm{AVE}$, this indicates that all the variables in the model are being estimated discriminant validity criteria.

\section{Composite Reliability}

The value of the composite reliability is carried out to test the reliability of variables. Variables 
Table 1. Respondent Data

\begin{tabular}{|c|c|c|c|c|}
\hline No & Variables & Classifications & Amount (people) & Percentage \\
\hline \multirow[t]{3}{*}{1} & \multirow{2}{*}{ Gender } & Men & 21 & $36.2 \%$ \\
\hline & & Women & 37 & $63.8 \%$ \\
\hline & Amount & & 58 & $100.0 \%$ \\
\hline \multirow[t]{7}{*}{2} & \multirow{6}{*}{ Age } & $24-30$ & 15 & $25,9 \%$ \\
\hline & & $31-37$ & 6 & $10.3 \%$ \\
\hline & & $38-44$ & 14 & $24.1 \%$ \\
\hline & & $45-51$ & 14 & $24.1 \%$ \\
\hline & & $52-58$ & 3 & $5.2 \%$ \\
\hline & & $59-66$ & 6 & $10.3 \%$ \\
\hline & Amount & & 58 & $100.0 \%$ \\
\hline \multirow[t]{4}{*}{3} & \multirow{3}{*}{ Education Background } & Elementary School & 18 & $31.0 \%$ \\
\hline & & Junior School & 14 & $24.1 \%$ \\
\hline & & Senior School & 26 & $44.8 \%$ \\
\hline & Amount & & 58 & $100.0 \%$ \\
\hline \multirow[t]{4}{*}{4} & & Single & 4 & $6.9 \%$ \\
\hline & Marital Status & Married & 53 & $91.4 \%$ \\
\hline & & Widow or Widower & 1 & $1.7 \%$ \\
\hline & Amount & & 58 & $100.0 \%$ \\
\hline \multirow[t]{4}{*}{5} & & $2-5$ tahun & 20 & $34,5 \%$ \\
\hline & Working Duration & $6-9$ tahun & 19 & $32.8 \%$ \\
\hline & & $>10$ tahun & 19 & $32.8 \%$ \\
\hline & Amount & & 58 & $100.0 \%$ \\
\hline \multirow[t]{3}{*}{6} & Occunation & Entrepreneur & 57 & $98.3 \%$ \\
\hline & Uccupation & Employees & 1 & $1.7 \%$ \\
\hline & Amount & & 58 & $100.0 \%$ \\
\hline \multirow[t]{7}{*}{7} & \multirow{6}{*}{ Facilities are obtained } & Productions tools & 14 & $24.1 \%$ \\
\hline & & Raw Materials & 3 & $5.2 \%$ \\
\hline & & Business Capital & & \\
\hline & & Loans & 2 & $3.4 \%$ \\
\hline & & Promotions & 19 & $32.8 \%$ \\
\hline & & Etc & 20 & $34.5 \%$ \\
\hline & Amount & & 58 & $100.0 \%$ \\
\hline \multirow[t]{7}{*}{8} & \multirow{6}{*}{ Monthly Income } & $<$ Rp. 2.000 .000 & 2 & $3.4 \%$ \\
\hline & & Rp. 3.000.000 - Rp. & & \\
\hline & & 6.000 .000 & 22 & $37.9 \%$ \\
\hline & & Rp. 7.000.000 - Rp. & & \\
\hline & & 10.000 .000 & 23 & $39.7 \%$ \\
\hline & & $>$ Rp.10.000.000 & 11 & $19.0 \%$ \\
\hline & Amount & & 58 & $100.0 \%$ \\
\hline
\end{tabular}


that good reliability can be show compositereliability value nor the cronbach alpha>0.60. Here is the presenting of the Table 2 as to the value of the composite reliability.

Table 2. Composite Reliability

\begin{tabular}{lcc}
\hline & $\begin{array}{c}\text { Composite } \\
\text { Reliability }\end{array}$ & $\begin{array}{c}\text { Cronbachs } \\
\text { Alpha }\end{array}$ \\
\hline I & 0,8427 & 0,7825 \\
KP & 0,8716 & 0,8100 \\
MS & 0,8180 & 0,7083 \\
OK & 0,7679 & 0,6857 \\
P & 0,8659 & 0,7925 \\
\hline
\end{tabular}

Bases on the Table 2, it can be noted that the entire value of the composite reliability or cronbachs alpha of each indicators already exceed 0.60 , thus it can be concluded that research already qualified variable reliability is good. Testing against the structural model is done by looking at the value of R-square which is a test for goodness-fit model. Testing inner structural model or models do to look at the relationship between variables, significance and value of $\mathrm{R}$ square model of research.

Bases on the Table 3 it can be known that in this study the relationship value most is the relationship between Innovation capability against the market, namely in the amount of $58,29 \%$, while the value of most small relationship is the relationship between social media marketing, namely against amounted to $2.87 \%$. In assessing models with PLS begins by looking at the R-Square for each dependent latent variable. Present in the Table 4 about the $\mathrm{R}$-square value of each variable research that is affected by other variables.

Table 3. Latent Variable Correlations
Table 4. $R$ Square

\begin{tabular}{lc}
\hline & R Square \\
\hline I & 0,0000 \\
KP & 0,3923 \\
MS & 0,0000 \\
OK & 0,0000 \\
P & 0,0963 \\
\hline
\end{tabular}

Bases on the Table 4 it can be interpreted that: a) market capabilities invalid constructs variability could be explained by the variability invalid constructs innovation, social capital and the entrepreneurial orientation value $39.2360 .76 \%$ explained by variables other than the ones examined. $b$ ) the marketing performance of invalid constructs variability could be explained by the variability of invalid constructs innovation, social capital, entrepreneurial orientation and market-value capabilities of 9.63\% whereas $90.37 \%$ explained by variables other than the ones examined.

\section{RESULT AND DISCUSSION}

Basis used in hypothesis testing is the value that is contained in the output result for inner weight In PLS statistically in any relationships that are hypothesized to be done with the simulation practice. In this case the hypothesis testing is done with the bootstrap sampling method. Testing with the bootstrap also meant to minimize problems of disorders research data. Application sampling methods allows the enactment data distribute free (free distribution) doesn't require the normal assumption distribution, and doesn't require a large sample. The statistical test used is the test

\begin{tabular}{cccccc}
\hline & $\mathbf{I}$ & $\mathbf{K P}$ & $\mathbf{M S}$ & $\mathbf{O K}$ & $\mathbf{P}$ \\
\hline $\mathrm{I}$ & 1 & 0,0000 & 0,0000 & 0,0000 & 0,0000 \\
$\mathrm{KP}$ & 0,5829 & 1 & 0,0000 & 0,0000 & 0,0000 \\
$\mathrm{MS}$ & 0,1872 & 0,3195 & 1 & 0,0000 & 0,0000 \\
$\mathrm{OK}$ & 0,4203 & 0,3423 & 0,1878 & 1 & 0,0000 \\
$\mathrm{P}$ & 0,3019 & 0,3103 & 0,0287 & 0,2858 & 1 \\
\hline
\end{tabular}


$\mathrm{t}$ significance of the parameter being estimated. Provide very useful information about the relationship between research variables. Present in the following Table 5 regarding path coefficients for testing hypotheses that have been proposed before.

Bases on the Path Coefficients chart above can be aware that the original sample value is found in the highest influence between innovation capabilities against the market, namely 0.5058 , whereas the original value of the lowest sample found on the influence between Entrepreneurial Orientation towards the market as follows the Capability of 0.0907. The value sample mean is found in the greatest influence among Innovation against the Market as follows Capability of 0.4609 , while the lowest values of the sample mean is found on the influence between Entrepreneurial Orientation towards Performance Marketing, i.e. of 0.1495 .

The value of the standard error (STERR) most present on the influence between the entrepreneurial Orientation towards the market as follows the $\mathrm{Ca}$ pability of 0.1622 , while the lowest value found on the influence between the Innovation Capabilities against the market, namely in the amount of 0.1174 . A value of the $t$-statistic between influences found in the largest Innovation against the Market Capability is 43.096, whereas a value of the $t$-statistic between the lowest influences present on Entrepreneurial Orientation towards Performance Marketing is 0.5593 . Table 6 is presented on the results of hypothesis testing on this research.

Bases on the hypothesis test results in table 6 bootstrapping from the analysis above can PLS note that the hypothesis 1, 3 and 4 are accepted, while hypotheses 2 is rejected. $\mathrm{H} 1$ is a hypothesis about the existence influence between social capital against
Market Capability, with a 5\% significance level, t-table 1.672 and t-statistic 17.378 , then it can be noted that the t-statistic greater than t-table, thus it can be concluded that $\mathrm{H} 1$ is accepted. Bases on the table above can also be noted that a positive coefficient on $\mathrm{H} 1$ 0.2077 then it can be inferred that the positive effect of social capital against Market Capability, which means the better social capital which is owned, then the higher the market capabilities for the resulting product. The findings of this research suitable by Chen et al. (2007).

$\mathrm{H} 2$ is a hypothesis concerning the influence between Entrepreneurial orientation towards the market Capability, with a 5\% significance level, t-table 1.672 and t-statistics 0.5593 , it can be noted that the $\mathrm{t}$-statistic is less than the $\mathrm{t}$-table, thus it can be concluded that $\mathrm{H} 2$ is refused. Bases on the table above can also be noted that a positive coefficient on $\mathrm{H} 20.0907$ then it can be inferred that the entrepreneurial orientation hasn't effect against the market capabilities, meaning that the better entrepreneurial orientation of small and medium business owners, then it will haven't effect on the capability resulting products in the market, this could happen on small and Medium Business batik as new running of its business due to the experience factors as segmentation factor, the market that aim hasn't been right. Halim research findings, 2012 is different with this research, entrepreneurial orientation effect significantly to market capabilities on a secondary effort in Southeast Sulawesi.

$\mathrm{H} 3$ is a hypothesis about the existence influence between Innovation Capability against the market, with a 5\% significance level, t-table 1.672 and t-statistic 43.096, then it can be noted that the t-statistic greater than $\mathrm{t}$-table, it can be inferred that the $\mathrm{H} 3$ is received. Bases on the table above can also be noted

Table 5. Path Coefficients (Mean, STDEV, T-Values)

\begin{tabular}{lccccc}
\hline & $\begin{array}{c}\text { Original Sample } \\
(\mathbf{O})\end{array}$ & $\begin{array}{c}\text { Sample } \\
\text { Mean (M) }\end{array}$ & $\begin{array}{c}\text { Standard } \\
\text { Deviation } \\
(\mathbf{S T D E V})\end{array}$ & $\begin{array}{c}\text { Standard Error } \\
(\mathbf{S T E R R})\end{array}$ & $\begin{array}{c}\text { T Statistics }(\mid \mathbf{O} / \\
\text { STERR } \mid)\end{array}$ \\
\hline I -> KP & 0,5058 & 0,4609 & 0,1174 & 0,1174 & 43,096 \\
KP -> P & 0,3103 & 0,3263 & 0,1458 & 0,1458 & 21,280 \\
MS - > KP & 0,2077 & 0,2262 & 0,1195 & 0,1195 & 17,378 \\
OK - KP & 0,0907 & 0,1495 & 0,1622 & 0,1622 & 0,5593 \\
\hline
\end{tabular}




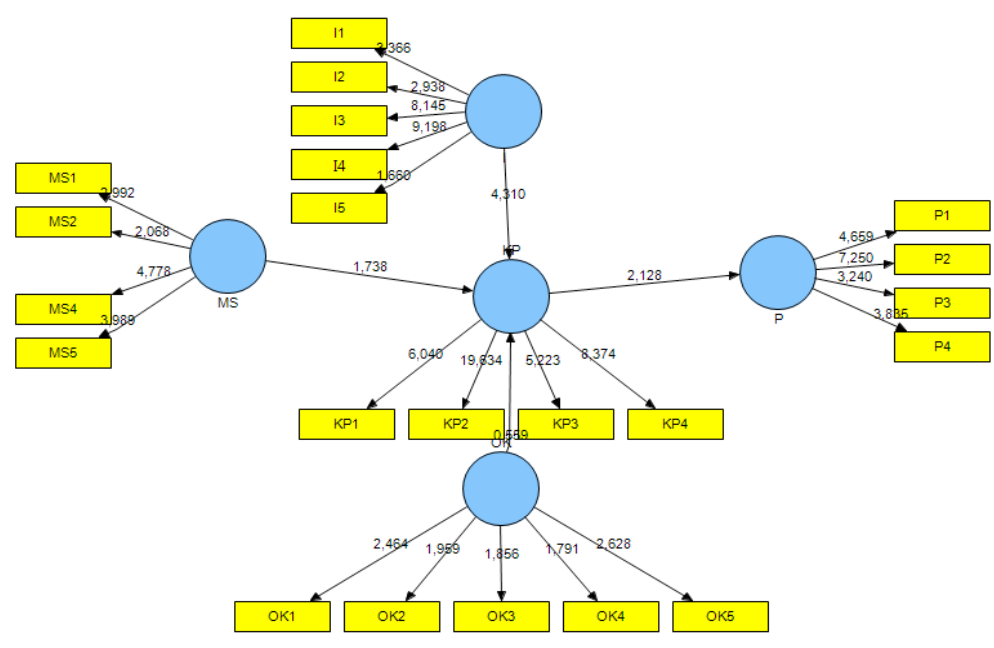

Figure 1. Research Model (Smart PLS 2.0)

that a positive coefficient on $\mathrm{H} 30.5058$ then it can be inferred that the positive effect of innovation against the market capabilities, it means that the higher innovation is done, then the higher market capability. This is in line with the results of the research study of Hatta (2014) at small and Medium Businesses restaurant hypotheses about the existence of the $\mathrm{H} 4$ is influence between market capability on performance marketing, with a 5\% significance level, t-table 1.672 and t-statistic 21.280 , then it can be noted that the $\mathrm{t}$ statistic greater than $\mathrm{t}$-table, it can be inferred that the $\mathrm{H} 4$ is received. Bases on the table above can also be noted that a positive coefficient on $\mathrm{H} 40.3103$ then it can be inferred that the market capabilities have positive effect on marketing performance, meaning that the higher market capability, then the higher performance marketing research findings is in line with this study of Indriastuti (2015) at a clothing industry in Central Java. Here is the presenting of the following Figure 1 as to show the research model with Smart PLS 2.0.

\section{CONCLUSION AND RECOMMENDATION}

The first hypothesis test results generate research findings illustrate the positive effect of social capital and its market capabilitiessignificantly, which means that the better social capital owned medium- small business can be increase batik market capabilities likes: sensing capabilities customers and competitors getting better. The second hypothesis results shows no effect on entrepreneurial orientation capability, meaning the better market orientation, entrepreneurship, owned small and medium business owners, will haven't effect on the market's capability in the product produce. The third hypothesis research results a positive effect towards the market innovation capabilities, the higher innovation means is performed, then the higher market capability. Hypothesis consists of four influential positive market capability on marketingperformance, meaning that the higher market capability, then, the higher marketingperformance.

Managerial implications from this research results the company must strengthen its capabilities in order to market resulting products are able to compete with other products. In addition the role of innovation has an important role in improving the marketing performance with increasing sales volume, number of customers, market expansion and Small Medium Business advantage. Theoretical implications of research to be performed increase variable market capabilities are shared by the two sensing capabilities customers and sensing capabilities competitors in order to have the competitive advantage of the product and its influence on marketing performance. 


\section{REFERENCES}

Barney, J. B. 1991. Firm Resources and Sustained Competitive Advantage. Journal of Management. 17(1): 99 - 120.

Chen, Cheng-Nan., Tzeng, Lun-Chung \& Ou, WeiMing. 2007. The Relationship Social Capital Entrepreneur Orientation, Organization Resource\& Entrepreneurial Performance for Ventura.Contemporary Management Research. 3(3): 213-232.

Coleman, J. 1988. Social Capital in the Creation of Human Capital. American Journal of Sociology.94 (Supplement): 95-120.

Cooke, P. 2007. Social capital, Embeddedness, and Market Interactions: An Analysis of Firm Performance in UK regions. Review of Social Economy. 65 (1): 79-106

Day, G. S. 1994. Capabilities of Market-Driven Organizations. Journal of Marketing. 58 (4): 37-52.

Drucker, P. F. 1986. Management: Task, Responsibilities, Practices, Truman.New York: Talley Books, E. P. Duttion

Ferdinand, A. 2005. Modal Sosial Dan Keunggulan Bersaing: Wajah Sosial Strategi Pemasaran. Semarang: Badan Penerbit Universitas Diponegoro.

Ferdinand, A. 2014. Metode Penelitian Manajemen. Edisi Kelima. Semarang: Badan Penerbit Universitas Diponegoro.

Ghozali, I. 2013. Analisis Multi Variate.Semarang: Penerbit Universitas Diponegoro Semarang.

Grant. R.M. 1991. The Recourced- Based Theory of Competitive Advantage: Implications for Strategy Formulation.California Management Review. 33(Spring):114-135.

Griffith, D., Noble S \& Chen Q. 2006. The Performance Implications of Entrepreneurial Proclivity: A Dynamic Capabilities Approach. Journal of Retailing. 82(1): 51-62.

Haroon, M \& Kocak, A. 2011. The Relationship Between Entrepreneurial Orientation Dynamic Capabilities and Firm Performance: An Exploratory Study of Small Turkish Firms. International J. Business and Globalisation. 7(3): 351-366.

Hatta, I. H. 2014. Analisis Pengaruh Inovasi, Pengambilan Resiko, Otonomi dan Reaksi Proaktif terhadap Kapabilitas Pemasaran UKM Kuliner Daerah Di Jabodetabek. Jurnal manajemen Pemasaran. 8(2): 90-96.
Hine, D \& Ryan, N. 1999 . Small Service Firm-Creating Valu trought Innovation. Managing Service Quality. 9 (6): 411-422.

Indriastuti. H. 2015. Membangun Kapabilitas Penginderaan Pasar, Inovasi Produk, Keunggulan Produk Modifikatif terhadap Kinerja Pemasaran. Prosiding. Presented at Managemen Dynamic Confrence, Seminar and Call Paper (MADIC), Fakultas Ekonoi Universitas Negeri Semarang, Semarang.

Mariam-Ismail. 2005. Creative Climate and Learning Organization Factors: Their Contribution Toward Innovation. Leadership \& Organization Development Journal. 26 (8) 639-654.

Mavondo. F.T., Chimhanzi. J \& Stewart. J. 2005. Learning Orientation and Market Orientation. European Journal of Marketing. 39(11/12): 1235-1263.

Merlo,O\& Auh,S.2009. The Effects of Entrepreneurial Orientation Market Orientation, and Marketing Subunit Influence on Firm Performance. Marketing Letter. 20 (3):295-311.

Narver, J.C \& Slater. 1990. The Effect of a Market Orientation on Business Profiitability.Journal of Marketing. 54 (4):20-35

Neely, A., Fillipini, R., Forza, Vinelli, A \& Hii, J. 2001. A Framework For Analizing Business Performance, Firm Innovation and Related Contextul Factors: Persption of Manager and Policy Makers in Two European Regions. Integrated Manufacturing System. 12(2): 114-124.

Paulina, I \& Wardoyo. 2012. Faktor Pendukung terhadap Intensi Berwirausaha pada Mahasiswa. Jurnal Dinamika Manajemen. 3 (1): 1-10.

Saeko, A. N., Chuntarung \&Thoumrungroje, P. 2012. The Impact of Integrated Marketing Strategy on Mareting Performance: An Empirical Evidence From Exporting Business in Thailand. International Journal of Business Strategy. 12 (4).

Tang,J., Tang, Z., Zhang, Y \& Li,Q.2007. The Impact of Entrepreneurial Orientation and Ownership Type on Firm Prformance in China. Jounal of Developmental Entrepreneurship. 12 (4): 383-397

Teece, D.J., Pisano, G \& Shuen, A. 1997. Dynamic Capabilities and Strategic Management. Strategic Management Journal. 18(7): 509-533.

Villena, V. H., Revilla, E \& Choi, T. Y. 2011. The Dark Side of Buyer-Supplier Relationships: A Social Capital Perspective. Journal of Opera- 
Naili Farida / Determinants of Marketing Performance...

tions Management. 29: 561-576.

Voss \& Voss, Z. 2000. Strategic Orientation Performance and Artistic Environment.Journal of Marketing. 64: 67-83.

Weber, C \& Weber, B. 2011. Exploring the Antecedents of Social Liabilities in CVC Triads: A Dynamic Social Network Perspective. Journal of Business Venturing. 26: 255-272.

Weerawerdana, J. 2003. Exploring The Role of Market Larning Capability in Competitive Strategy. European Journal of Marketing. 37: 407429.

Wernefelt, B.1984 . A Resource-based View of the Firm. Strategic Management Journal. 5: 171-180.
Wincent, J., Thorgren, S \& Anokhin, S. 2013. Managing Maturing Government-Supported Networks: The Shift from Monitoring to Embeddedness Controls. British Journal of Management. 24: 480-497.

Wincent, J., Thorgren, S \& Anokhin, S. 2014. Entrepreneurial Orientation and Network Board Diversity in Network Organizations. Journal of Business Venturing. 29: 327-344.

Yulianto, A. 2010. Meningkatkah Kualitas Pelayanan Jasa Penerbangan Indonesia Paska Insiden Kecelakaan Pesawat Terbang? Jurnal Dinamika Manajemen. 1(1): 1-8. 